\title{
Challenges in Post-Disaster Housing Reconstruction: Analysis of Urban vs. Rural Communities
}

\author{
Apurva Pamidimukkala ${ }^{1}$, Sharareh Kermanshachi ${ }^{2}$ and Elnaz Safapour ${ }^{3}$
}

1 Department of Civil Engineering, University of Texas at Arlington, Arlington, USA, apurva.pamidmukkala@mavs.uta.edu

2 Department of Civil Engineering, University of Texas at Arlington, Arlington, USA, sharareh.kermanshachi@uta.edu

3 Department of Civil Engineering, University of Texas at Arlington, Arlington, USA, elnaz.safapour@mavs.uta.edu

\begin{abstract}
Reconstruction of safe and secure housing is commonly considered the most effective means of returning rural and urban communities affected by disasters to pre-disaster living conditions. In addition, the reconstruction process and the degree of its success greatly impacts the community's ability to work through the next disaster. The various challenges that the reconstruction process encounters have been identified, investigated, and analyzed in this study. After reviewing 177 articles in detail, approximately 30\% of which pertained to reconstruction of houses after earthquakes, 54 challenges were identified and placed into four categories: general, physical, social, and economic. About 30\% of the reviewed articles were studied the challenges of housing reconstruction after earthquake. In addition, the journal of Disaster received the highest frequency (37) among the reviewed papers in which the challenges of housing reconstruction after disaster in urban and rural communities were studied. This study succinctly assists decision-makers and project managers allocate needed resources effectively and improve the performance of post-disaster reconstruction of housing in both rural and urban areas.
\end{abstract}

(c) 2020 The Authors. Published by Budapest University of Technology and Economics \& Diamond Congress Ltd Peer-review under responsibility of the Scientific Committee of the Creative Construction Conference 2020.

Keywords: post-disaster recovery, housing, reconstruction, rural, communities

\section{Introduction}

Considerable damages that governments cannot prevent often occur from natural disasters [1, 2, 3]. Different parts of the world have been faced recently with numerous natural disasters that have caused substantial losses $[4,5]$. For example, when Hurricane Harvey occurred in the southern part of Texas in 2017, it destroyed a considerable number of buildings and houses and displaced residents. This type of destruction is common in both rural and urban areas, and often leads to displacing residents permanently $[6,7]$.

Multiple studies have been conducted to optimize the post-disaster reconstruction of housing in urban and rural communities and to maximize the outcomes of those efforts [1, 5, and 8]. Even so, few researchers have analyzed the rural and urban challenges simultaneously, which is the goal of this study.

A thorough review of 177 scholarly papers provided the background for investigating the challenges associated with post-disaster reconstruction of housing and formulating the following objectives: (1) identify the challenges, (2) categorize the identified challenges, (3) calculate the frequency that the challenges occur, and (4) rank the challenges based on the frequency of them. The findings of this study 
can help practitioners assess the challenges associated with post-disaster reconstruction of housing in both urban and rural communities so that they can allocate their resources properly.

\section{Research methodology}

More than 300 journal articles, conference papers, and research reports published from 2000 to 2019 were studied. More than two-thirds of them were journal papers, and the others were research reports, conference proceedings and dissertations. A four-step methodology was adopted for this study, as presented in Figure 1. Five major databases, including Google Scholar, Science Direct, Compendex, Inspec, and ProQuest were used to collect the articles, and the essential information, like the name of the journal, the disaster type, and the challenges related to post-disaster recovery were presented. As shown in Figure 1 , the challenges were categorized, then their frequencies and ranks were calculated.

\begin{tabular}{|cl|}
\hline \multicolumn{2}{|c|}{$\begin{array}{c}\text { Literature Review and Data } \\
\text { Collection }\end{array}$} \\
\hline$\circ$ & Inspec \\
$\circ$ & Compendex \\
$\circ$ & Google scholar \\
$\circ$ & Science Direct \\
$\circ$ & ProQuest \\
\hline
\end{tabular}
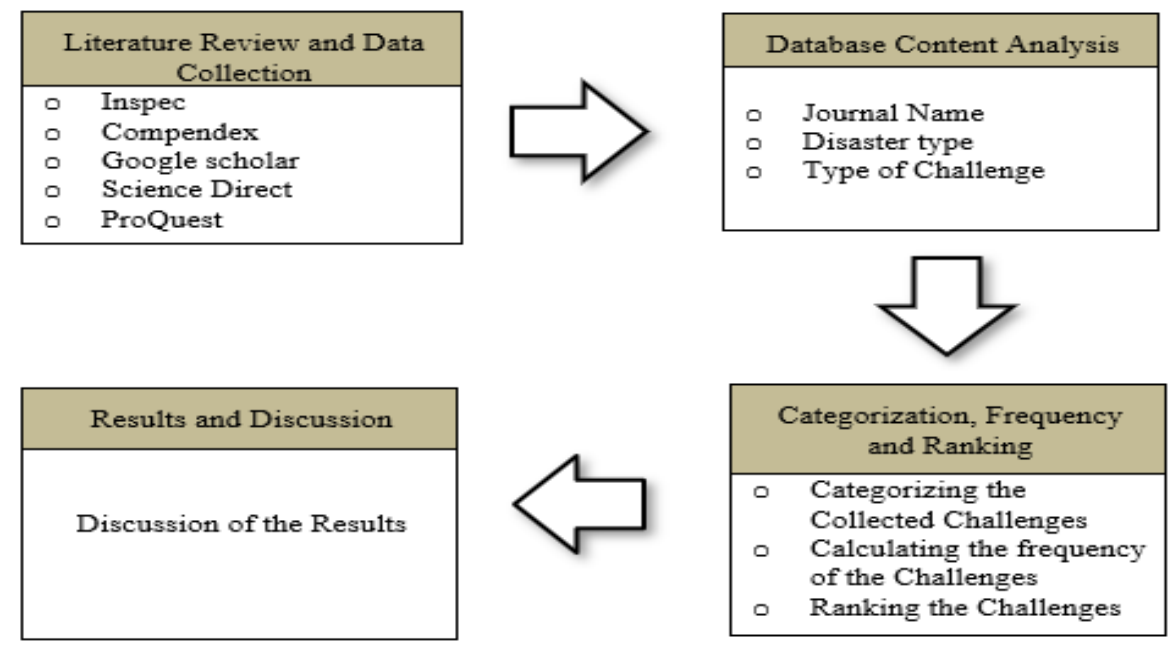

Figure 1. Research methodology

\subsection{Journal name}

For this study, 177 related journal articles issued by well- established publishers from the years 2000 to 2020 were carefully reviewed to identify the challenges associated with post-disaster reconstruction of housing in both urban and rural communities, and a list of them, with their frequencies and percentages, is presented in Table 1. The first five journals listed published 69 percent of the articles. The Disasters journal, which is published by the Overseas Development Institute, ranked first and was the source of $21 \%$ of the total number of the papers. The International Journal of Project Management, which is published in collaboration with the Association for Project Management and the International Project Management Association, ranked second with $16 \%$.

Table 1. Frequency and percentage of reviewed articles based on journals

\begin{tabular}{lcc}
\hline Journal Name & Frequency & Percentage \\
\hline Disasters & 37 & 21 \\
International Journal of Project Management & 28 & 16 \\
Communication & 22 & 12 \\
International Journal of Strategic Property Management & 19 & 11 \\
International Journal of Disaster Resilience in the Built Environment & 15 & 9 \\
Journal of Contingencies and Crisis Management & 10 & 6 \\
Journal of Architecture & 7 & 4 \\
Administration \& Society & 6 & 3 \\
Computer-aided Civil and Infrastructure Engineering & 4 & 2 \\
Journal of Geographical Sciences & 4 & 2 \\
Eastern Geographical Review & 3 & 2 \\
Habitat International & 2 & 1 \\
Journal of Management in Engineering & 2 & 1 \\
Other journals & 18 & 10 \\
\hline Total & 177 & 100 \\
\hline
\end{tabular}




\subsection{Disaster type}

The types of disasters were grouped according to various considerations. Some disasters, such as earthquakes, have a sudden impact on society [9], while others like droughts and storms impact the community very slowly [10]. Figure 2 shows the distribution of papers based on disaster type. As shown in Figure 2 , about $30 \%$ of the articles studied the post-disaster reconstruction of housing after earthquakes.

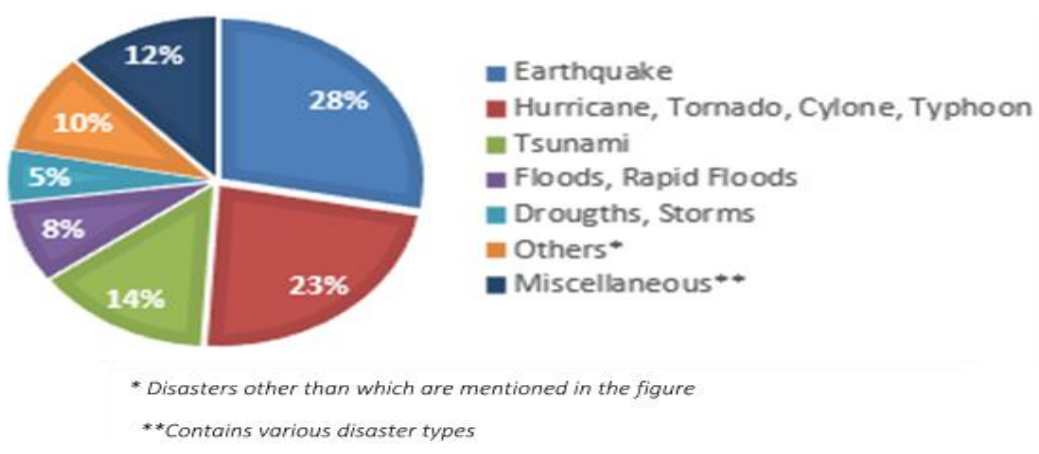

Figure 2. Distribution of papers according to the disaster types

\section{Post-disaster reconstruction of housing in urban and rural areas}

Post-disaster reconstruction of housing in rural and urban areas presents challenges that are specific to each area. Inspired by the studies conducted by Yilmaz et al. [11] and Alipour et al. [12], the authors of the present review categorized the challenges identified through the existing literature into four main categories: general, economic, social, and physical.

\subsection{General challenges}

The general challenges are presented in Table 2 and were classified into six main categories: (1) resources, (2) planning and management, (3) land values, (4) occupancy and interaction, and (5) population, and (6) occupation. The frequency of the challenges in each category was counted, and the categories were ranked. As illustrated in Table 2, the challenges belonging to the resource category received the highest frequency (55) and were recorded as the first rank. The challenges belonging to the planning and management category received the second highest frequency (32).

Gur [13] and Arslan [14] believed that the size of the population in the affected area plays a crucial role in the length of time required to complete the housing reconstruction. Since urban areas are usually more populated than rural areas, the reconstruction would be expected to take longer in them [15]. Effective management is another important element associated with housing reconstruction after a disaster [16]. According to the studies conducted by Alipour et al. [12], it is easier to establish effective communication and coordination among those in a rural area because rural communities commonly follow their local leaders, while those in urban communities want to know every detail of the process, making the controlling and management of them complicated [17].

In 2013, Tafti and Tomlinson conducted a study in which it was concluded that the affected families/individuals who own the houses that are destroyed are more willing to participate actively in the process of reconstruction. Accordingly, as rural people are usually homeowners and live in their houses, they are active in the reconstruction process. On the contrary, some of the people in the urban areas are tenants and often do not fully participate in the reconstruction. 
Table 2. List of general challenges and their categories, frequencies, and ranking

\begin{tabular}{|c|c|c|c|c|}
\hline Category & Challenge & Previous studies & Frequency & Ranking \\
\hline Resources & $\begin{array}{l}\text { - Availability of public } \\
\text { facilities } \\
\text { - Accessibility to } \\
\text { resources } \\
\text { - Competing demand for } \\
\text { resources } \\
\text { - Scarcity of resources }\end{array}$ & {$[18,19,20,21,22,23]$} & 55 & 1 \\
\hline $\begin{array}{l}\text { Planning and } \\
\text { Management }\end{array}$ & $\begin{array}{l}\text { - Institutional capacity } \\
\text { for planning and } \\
\text { regulation } \\
\text { - Inadequate planning } \\
\text { - Inadequate operational } \\
\text { management related to } \\
\text { post disaster recovery } \\
\text { - Effective management }\end{array}$ & {$[12,21,24,25,26,27]$} & 32 & 2 \\
\hline Land issues & $\begin{array}{l}\text { - Land Values } \\
\text { - Shortage of land for } \\
\text { relocation }\end{array}$ & {$[23,28,29,30]$} & 21 & 3 \\
\hline $\begin{array}{l}\text { Occupancy } \\
\text { and } \\
\text { Interaction }\end{array}$ & $\begin{array}{l}\text { - Ownership status } \\
\text { - Type of occupancy } \\
\text { - Interaction between } \\
\text { neighbors }\end{array}$ & {$[13,30]$} & 16 & 4 \\
\hline Population & $\begin{array}{l}\text { - Level of expectations } \\
\text { - Number of population }\end{array}$ & {$[13,14,31,32]$} & 5 & 5 \\
\hline Occupation & - Farming Habits & {$[18,23]$} & 2 & 6 \\
\hline
\end{tabular}

Boen and Jigyasu [23] found that farming habits are a major challenge in rural areas. The farmers they studied, who were relocated from their native place during a natural disaster, were unable to cope with their new environment, as it required changing their farming habits. The land provided to them for farming might not grow the varieties of crops that they were accustomed to growing, and it was sometimes located far from where they were staying. This caused the farmers to abandon the place they were relocated to and return to their native places to rebuild their houses.

\subsection{Social challenges}

The social challenges associated with post-disaster reconstruction of housing in urban and rural communities were identified by conducting a comprehensive review, and the results are shown in Table 3. The challenges were classified into five main categories: (1) literacy, (2) culture, (3) lifestyle, (4) community, and (5) government services. The frequency of the social challenges belonging to each category that were cited in the existing literature was counted and the categories were ranked.

As indicated in Table 3, one of the critical challenges associated with post-disaster reconstruction of housing is effectively involving the community in the process [33, 34] In 2010, Jha et al. [35] explained that affected people in rural areas participate actively in the process because they know and trust each other and the responsible organizations, and the advertising is very easy, as it consists mostly of just talking to one another. Conversely, the structure of an urban area is usually complicated, and it is difficult to encourage and/or convince the urbanites to participate [36]. 


\begin{tabular}{|c|c|c|c|c|}
\hline Category & Challenge & Previous studies & Frequency & Rank \\
\hline Literacy & $\begin{array}{l}\text { - Education level } \\
\text { - Level of public awareness }\end{array}$ & {$[26,37,38]$} & 24 & 1 \\
\hline Culture & $\begin{array}{l}\text { - Cultural disparities after } \\
\text { relocation } \\
\text { - Level of required privacy }\end{array}$ & {$[39,40,41,42,43,44,45]$} & 19 & 2 \\
\hline Lifestyle & $\begin{array}{l}\text { - Poverty, Inequality, and } \\
\text { unemployment } \\
\text { - Capability of self-settlement } \\
\text { - Level of healthcare } \\
\text { - Loss of livelihood } \\
\text { - Using of modern technology }\end{array}$ & {$[23,33,46,47,48,49,50]$} & 15 & 3 \\
\hline $\begin{array}{l}\text { Participation } \\
\text { and } \\
\text { Mobilization }\end{array}$ & $\begin{array}{l}\text {-Public participation } \\
\text {-Insufficient time allowed for } \\
\text { community mobilization }\end{array}$ & {$[14,21,25,33,40,51]$} & 14 & 4 \\
\hline $\begin{array}{l}\text { Government } \\
\text { Services }\end{array}$ & $\begin{array}{l}\text { - Local social capital } \\
\text {-Availability of social services }\end{array}$ & {$[42,52]$} & 10 & 5 \\
\hline
\end{tabular}

As presented in Table 3, Peng et al. [47] stated that a community's capabilities play a significant role in the length of time needed to complete housing reconstruction after a disaster. The people in rural communities are usually capable of self-settlement and work hard to expedite the reconstruction process, while urban people are more dependent on governments and other responsible organizations doing it for them.

Table 3 indicates that community participation is one of the major challenges. After any disaster, it is very common that the affected people are ignored in the process of decision-making [51]. The lack of public participation overshadows the real demand of the affected people [33,53].

\subsection{Economic challenges}

The challenges associated with economics and finance were identified through the existing literature and are presented in Table 4, which shows that the economic challenges were classified into three categories: financial resources, management, and the local economic level. The frequency of the challenges belonging to each of the categories was calculated and ranked. 
Table 4. List of economic challenges and their categories, frequencies, and ranking

\begin{tabular}{|c|c|c|c|c|}
\hline Category & Challenge & Previous Studies & Frequency & Rank \\
\hline $\begin{array}{l}\text { Financial } \\
\text { Resources }\end{array}$ & $\begin{array}{l}\text { - Availability of financial resources } \\
\text { - Lack of funding } \\
\text { - Extraordinary financial requirements }\end{array}$ & {$[54,55,56,57,58,59,60]$} & 41 & 1 \\
\hline Management & $\begin{array}{l}\text { - Availability of multiple source } \\
\text { procurement } \\
\text { - Availability of economic monitoring } \\
\text { - Local economic engagement } \\
\text { - Financial management }\end{array}$ & {$[19,37,43,58,61,62]$} & 14 & 3 \\
\hline $\begin{array}{l}\text { Local } \\
\text { Economic } \\
\text { Level }\end{array}$ & $\begin{array}{l}\text { - Affordability of essential needs } \\
\text { - Income level } \\
\text { - Local economic level }\end{array}$ & {$[38,52,63]$} & 12 & 5 \\
\hline
\end{tabular}

As indicated in Table 4, the income level of the affected people is a major challenge to housing reconstruction after a disaster [38]. As rural people commonly have a low/limited level of income from occupations such as fishing and agriculture, they cannot afford their essential needs through a postdisaster time [63]. Governments and responsible organizations have to face these economic challenges by distributing and/or investing available funding throughout the process of housing reconstruction.

\subsection{Physical challenges}

The physical challenges associated with housing reconstruction in both rural and urban areas after a disaster were determined from the existing literature and are shown in Table 5 . The challenges were classified into six categories: (1) quality, (2) construction team, (3) design, (4) transportation, (5) safety, and (6) nature of the land. The frequency of the physical challenges was calculated, and then the related ranking was counted.

Table 5 indicates that the sizes of the houses and the number of rooms in them is very important for completing post-disaster reconstruction [38,64]. In 2010, Onder et al. [33] conducted a study in which they demonstrated that the duration of post-disaster reconstruction in the urban areas may be longer than in rural areas because the houses and rooms in urban areas are usually larger.

Table 5. List of physical challenges and their categories, frequencies, and ranking

\begin{tabular}{|c|c|c|c|c|}
\hline Category & Challenge & Previous Studies & Frequency & Rank \\
\hline Quality & $\begin{array}{l}\text { - Quality of construction } \\
\text { - Quality of materials }\end{array}$ & {$[42,65,66]$} & 30 & 1 \\
\hline $\begin{array}{l}\text { Construction } \\
\text { Team }\end{array}$ & $\begin{array}{l}\text { - Absence of proper } \\
\text { technical assistance } \\
\text { - Inexperienced construction } \\
\text { management team }\end{array}$ & {$[23,25,43,67]$} & 22 & 2 \\
\hline Design & $\begin{array}{l}\text { - Size of houses and rooms } \\
\text { - Complexity of design } \\
\text { - New or improved building } \\
\text { codes }\end{array}$ & {$[38,42,68,69,70]$} & 16 & 3 \\
\hline Transportation & $\begin{array}{l}\text { - Availability of } \\
\text { transportation services } \\
\text { - Distance to city center and } \\
\text { other services }\end{array}$ & {$[31,37,52,71]$} & 12 & 4 \\
\hline Safety & $\begin{array}{l}\text { - Health and safety } \\
\text { management issues } \\
\text { - Environmental risk } \\
\text { - Exposure to hazardous } \\
\text { materials }\end{array}$ & {$[21,54,68,72,73]$} & 11 & 5 \\
\hline
\end{tabular}




\begin{tabular}{|c|c|c|c|c|}
\hline Nature of Land & $\begin{array}{l}\text { - Complex urban landscape } \\
\text { - Geological nature of } \\
\text { resettlement site } \\
\text { - Remoteness and } \\
\text { geography }\end{array}$ & {$[72,74,75]$} & 4 & 6 \\
\hline
\end{tabular}

Gok [69] and Gok et al. [70] believed than complex designs make housing reconstruction difficult and more subject to multiple issues. Because the designs of urban houses are usually more complex than those of rural houses, their reconstruction can be complicated and more subject to schedule delays and cost overruns [76]

As indicated in Table 5, one of the major challenges to reconstruction is the quality and scale of the work [77], which is often far beyond the capacity of the accessible inspectors. After a disaster, the normal regulations, design requirements, and permits are suspended in order to speed up the construction [78] This leads to inspectors with heavy workloads and results in poor inspections [66]. In one case in Indonesia, the poor quality of the housing constructed by a nongovernmental organization was unacceptable to the communities, and about 300 houses were destroyed [65].

\section{Conclusion}

In this study, 177 articles were thoroughly reviewed to identify the challenges associated with post-disaster reconstruction of housing in urban and rural areas. The challenges were classified into general, social, economic, and physical categories. The frequency of the reviewed journals was then calculated, and their ranking was counted. The results revealed that there are remarkable differences between policies of postdisaster reconstruction of rural housing and urban housing. Additionally, effectively communicating with and coordinating the activities of people in a rural area is easier than it is with people in an urban area. The results also demonstrated that affected families/individuals who own the houses that were destroyed are more willing to participate actively in the process of reconstruction. Accordingly, as rural people are usually homeowners and live in their own houses, they are more active in the reconstruction process. On the contrary, some of the urban people in the affected areas are tenants, rather than homeowners, and they often do not fully participate in the reconstruction process. This study will help project managers allocate resources effectively and enhance the outcomes of post-disaster reconstruction of housing in both rural and urban areas.

\section{References}

[1] Nejat, A., and Damnjanovic, I. "Agent-based modeling of behavioral housing recovery following disasters." Computer-aided Civil and Infrastructure Engineering, 27, 748-763, 2012. https://doi.org/10.1111/j.1467-8667.2012.00787.x

[2] Kermanshachi S., and Rouhanizadeh, B. "Feasibility Analysis of Post Disaster Reconstruction Alternatives Using Automated BIMBased Construction Cost Estimation Tool". CSCE 6th International Disaster Mitigation Specialty conference, 2018

[3] Kermanshachi, S., Bergstrand, K. and Rouhanizadeh, B. "Identifying, Weighting and Causality Modeling of Social and Economic Barriers to Rapid Infrastructure Recovery from Natural Disasters: A Study of Hurricanes Harvey, Irma and Maria," Technical Report, U.S. Department of Transportation, C-TEDD, January 2019.

[4] Fuchs, S. "Against essentialism: A theory of culture and society." American Journal of Sociology Cambridge, MA: Harvard University Press, 2001

[5] Eid, M. S., and El-adaway, I. H. "Integrating the social vulnerability of host communities and the objective functions of associated stakeholders during disaster recovery processes using agent-based modeling." Journal of Computing in Civil Engineering, 31(5), 04017030, 2017. https://doi.org/10.1061/(ASCE)CP.1943-5487.0000680

[6] Picou, J. S., and Marshall, B. K. "Katrina as a paradigm shift: Reflections on disaster research in the twenty-first century." In D. L. Brunsma, D. Overfelt, \& J. S. Picou (Eds.), The sociology of Katrina: Perspectives on a modern catastrophe. Lanham, MD: Rowman \& Littlefield, 1-20, 2007. https://doi.org/10.1111j.1530-2415.2008.00164.x

[7] Rouhanizadeh, B and Kermanshachi S. "Investigating the Relationships of Socioeconomic Factors Delaying Post-Disaster Reconstruction". ASCE International Conference on Computing in Civil Engineering, 2019. https://doi.org/10.1061/9780784482445.005

[8] Haimes, Y. Y. "Systems-based approach to preparedness for, response to, and recovery from natural and human-made disasters." Leadership and Management in Engineering, 288-298, 2012. https://doi.org/10.1061/(ASCE)LM.1943-5630.0000183

[9] Rouhanizadeh B, Kermanshachi S, and Dhamangaonkar V S. Reconstruction of Critical and Interdependent Infrastructures due to Catastrophic Natural Disasters: Lessons Learned. ASCE Construction Research Congress (CRC), 2019

[10] Nipa T, J, Kermanshachi S, Ronik K P, Taffazoli M. "Disaster Preparedness Education: Construction Curriculum Requirements to Increase Students' Preparedness in Pre-and Post-Disaster Activities", Associated Schools of Construction (ASC) International Conference, 2020

[11] Yilmaz, D. G., Meding, J. V., and Erk, G. K. "A theoretical approach to the design of a survey instrument in post-disaster reconstruction: Defining indicators for a human-based study in rural built-environment." International Journal of Architectural Research, 7(3), 40-56, 2013, https://doi.org/10.26687/archnet-ijar.v7i3.48 
[12] Alipour, F., Khandeh, H. R., Fekrazad, H., Kamali, M., Rafeiy, H., Sarrami Foroushani, P., Rowell, K., and Ahmadi, S. "Challenges for resuming normal life after earthquake: A qualitative study on rural areas of Iran." PLoS Currents, Version 1, 2014. https://doi.org/ $10.1371 /$ currents.dis.b4e84b942500e2f8f260f3471b7ee815

[13] Gur, M. "An investigation on user satisfaction in TOKI constructions for low- and middle-income people: The example of Bursa," MSc. Thesis, Uludag University, The Institute of Science and Technology, Department of Architecture, Bursa, Turkey, 2009.

[14] Arslan, H., \& Unlu, A. "The Evaluation of Community Participation in Housing "Reconstruction Projects after Duzce Earthquake," Proceeding of International Conference and Student Competition on post-disaster reconstruction, 2006.

[15] Safapour E, and Kermanshachi S. "Investigation of the Challenges and Their Best Practices for Post-Disaster Reconstruction Safety: Educational Approach for Construction Hazards". Transportation Research Board 99th Annual Conference, 2019

[16] Shaw, J.; Ahmed, I. "Design and delivery of post disaster housing resettlement programs: case studies from Sri Lanka and India." Report 6. Monash Asia Institute, Monash University, 2010.

[17] Shirin K, R and Kermanshachi S. "Development of Project Communication Network: A New Approach to Information Flow Modeling". Construction Research Congress (CRC), 2017. https://doi.org/10.1061/9780784481271.042

[18] Richard Haigh, Siri Hettige, Maheshika Sakalasuriya, G. Vickneswaran, Lasantha Namal Weerasena. "A study of housing reconstruction and social cohesion among conflict and tsunami affected communities in Srilanka". Disaster prevention and management, 25 (5). Pp. 566580, 2016. https://doi.org/10.1108/DPM-04-2016-0070

[19] Chang-Richards, Y., Wilkinson, S., Potangaroa, R., and Seville, E "Resource challenges for housing reconstruction: a longitudinal study of the Australian bushfires, Disaster Prevention and Management". An International Journal 22(2), 172-181, 2013 https://doi.org/10.1108/09653561311325316

[20] Tas, N., Tas, M., and Cosgun, N. "Permanent housing production process after 17 August 1999 Marmara Earthquake in Turkey," International Journal of Strategic Property Management, 15, 312-32, 2011. http://doi.org/10.3846/1648715X.2011.617863

[21] Kennedy, J., Ashmore, J., Babister, E., Kelman, I. "The Meaning of Build Back Better: Evidence from Post Tsunami Aceh and Sri Lanka". Journal of Contingencies and Crisis Management 16(1), 24-36, 2008. https://doi.org/10.1111/j.1468-5973.2008.00529.x

[22] O'Brien, D., Ahmed, I. and Hes, D. "Housing reconstruction in Aceh: relationships between house type and environmental sustainability". Building Abroad: Procurement of Construction and Reconstruction Projects in the International Context', Montreal Group de Recherche IF, grif, University of Montreal, Montreal, Canada, 2008.

[23] Teddy Boen, Rohit Jigyasu "Cultural Considerations for Post Disaster Reconstruction Post-Tsunami Challenges", 2005

[24] Moloney A. "Haitians still homeless, suffering in despair 4 years after quake-Amnesty". Thomson Reuters Foundation, Pp: 4-6, 2014

[25] Ophiyandri, T., Amaratunga, R. D. G., Pathirage, C. P. "Community Based Post Disaster Housing Reconstruction: Indonesian perspective", 2010

[26] Ophiyandry, T., Amaratunga, D., Keaminiyage, K. "Advantages and limitations of community-based post-disaster housing reconstruction project." International Journal of Disaster Resilience in the Built Environment, 7(4), 420-431, 2015. https://doi.org/10.1108/ijdrbe-08-2014-0066

[27] Assaf \& Al-hejji. "Causes of Delay in Large Construction Projects". International Journal of Project Management 24(4), 349-357. 2006. https://doi.org/10.1016/j.jproman.2005.11.010

[28] Fayazi, M., and Lizarralde, G. "The impact of post-disaster housing reconstruction policies on different beneficiary groups: The case of Bam, Iran." Springer International Publishing AG, part of Springer Nature, 2019. https://doi.org/10.1007/978-3-319-92498-4_9

[29] Lizarralde, G. "The invisible houses: Rethinking and designing low-cost housing in developing countries." London: Routledge 2015. https://doi.org/10.4324/9781315749600

[30] Uyangoda, J. "Post-Tsunami Recovery in Sri Lanka”. Polity 2, 3. Social Sciences Association of Sri Lanka, Colombo, 2005.

[31] Barenstein, J. "From Gujarat to Tamil Nadu: Owner-driven vs. contractor-driven housing reconstruction in India". Proceedings in the 4th international i-Rec conference: building resilience, 2008.

[32] Darkwa, I. "Post-Occupancy Evaluation of State-Subsidised Housing Units in Kayamandi- Stellenbosch," MSc. Thesis in Consumer Science, University of Stellenbosch, Stellenbosch, South Africa, 2006. https://doi.org/10.17159/sajs.2015/20140354

[33] Keshab Sharma, Apil KC, Mandip Subedi, Bigul Pokharel. "Post Disaster Reconstruction after Gorkha Earthquake: Challenges and Influencing Factors". 2018. https://doi.org/10.3126/jie.v14i1.20068

[34] Rouhanizadeh B and Kermanshachi S. "Gender-Based Evaluation of Physical, Social, and Economic Challenges in Natural Disasters Management". ASCE construction research congress (CRC), 2019

[35] Jha, A. K., Barenstein, J. D., Phelps, P. M., Pittet, D., Sena, S. "Safer homes, stronger communities: a handbook for reconstructing after natural disasters." The World Bank, Washington, 2010. https://doi.org/10.1596/978-0-8213-8045-1

[36] Rouhanizadeh B, Kermanshachi S and Dhamangaonkar V S. "Identification and Categorization of Policy and Legal Barriers to LongTerm Timely Post- Disaster Reconstruction". Journal of Legal Affairs and Dispute Resolution in Engineering and Construction, 2019. https://doi.org//10.1061/(ASCE)LA.1943-4170.0000307

[37] Tercan, B. "Relocation and Resettlement Policies on Disaster Areas: The Case of Doğubayazıt Province and Four Villages," PhD Thesis, Ankara University, The Graduate School of Social Sciences, Department of Politics and Public Administration, Ankara, Turkey, 2008

[38] Mohapatra, R. "Community Based Planning in Post-Disaster Reconstruction: A Case Study of Tsunami Affected Fishing Communities in Tamil Nadu Coast of India." PhD Thesis, University of Waterloo, Department of Planning, Waterloo, Ontario, Canada. (2009).

[39] Mukherji, A. "Post-disaster housing recovery." Oxford Research Encyclopedia of Natural Hazard Science, Oxford University Press, 2017. https://doi.org/10.1093/acrefore/9780199389407.013.82

[40] Zhou, G. H., He, Y. Y., and Tang, C. L. "Dynamic mechanism and present situation of rural settlements evolution in China (in Chinese)." Journal of Geographical Sciences 66(4), 515-524. 2011.

[41] Hidayat, B and Egbu, C. "Critical success factors associated with post-disaster reconstruction projects In: Egbu, C. and Lou, E.C.W. (Eds.)". Procs 27th Annual ARCOM Conference, 5-7 September 2011, Bristol, UK, Association of Researchers in Construction Management, 889-898, 2011.

[42] Onder, D. E., Koseoglu, E., Bilen, O., and Der, V. "The effect of user participation in satisfaction: Beyciler after earthquake houses in Duzce," Journal of Architecture, 7(1), 18-37, 2010.

[43] Barenstein, J. D. "Housing reconstruction in post· earthquake Gujarat: a comparative analysis," Network Paper 54, Commissioned and published by the Humanitarian Practice Network at Overseas Development Institute, London, 2006

[44] Pardasani, M. "Tsunami reconstruction and redevelopment in the Maldives. A case study of community participation and social action", Disaster Prevention and Management, 2006. https://doi.org/10.1108/09653560610654257

[45] Barakat, S. "Housing Reconstruction after Conflict and Disaster". Hum Pol Group, Network Papers 43, 1-40, 2008. 
[46] Ram Sharan Mahat, "Toward a resilient Nepal" End Poverty in South Asia, South Asian Region of the World Bank Group, 2015

[47] Peng, Y., Shen, L., Tan, C., Tan, D., and Wang, H. "Critical determinant factors (CDFs) for developing concentrated rural settlement in post-disaster reconstruction: A China study." Natural Hazards, 66, 355-373, 2013. https://doi.org/10.1007/s11069-012-0488-7

[48] Dye, C. "Health and urban living." Science 319(5864), 766-769, 2008.

[49] Adger, W. N., Brooks, N., Betham, G., Agnew, M., and Eriksen, S. "New indicators of vulnerability and adaptive capacity," Tyndall Centre for Climate Change Research, Technical Report 7, 2004.

[50] Zappettini, K. "Rural Self-Help Housing: A Post-Occupancy Evaluation of Homeowners' Satisfaction with Residential Space Plan and Housing Quality," Virginia Polytechnic Institute and State University, PhD Thesis in Near Environments, Blacksburg, Virginia, USA ,2001.

[51] Emmanuel Raju "Housing Reconstruction in Disaster Recovery: A Study of Fishing Communities Post-Tsunami in Chennai, India". Plos currents disasters, 2013. https://doi.org/10.1371/currents.dis.a4f34a96cb91aaffacd36f5ce7476a36

[52] CURBE "Disaster Recovery Indicators: guidelines for monitoring and evaluation," Cambridge University Centre for Risk in the Built Environment, 2010.

[53] Nipa T H, and Kermanshachi S. Identification of the Resilience Dimensions and Determination of their Relationships in Critical Transportation Infrastructures. ASCE Construction Research Congress (CRC), 2019

[54] Bilau, A. A., Witt, E., and Lill, I. "Housing reconstruction following the 2012 nigerian floods: Was it built back better?" In Proceedings of the CIB World Building Congress, Volume II, Tampere, Finland, 30 May-3 June 2016

[55] May, P. J. "Public risks, and disaster resilience: Rethinking public and private sector roles". In N. Kapucu, C. V. Hawkins, \& F. I. Rivera (Eds.), Disaster resiliency: Interdisciplinary perspectives (pp. 126-145). New York: Routledge, 2013 https://doi.org/10.1108/dpm-122015-0279

[56] Trohanis, Z.; and Read, G. "Housing Reconstruction in Urban and Rural Areas". The World Bank: Washington, DC, USA, 2010.

[57] McKeon, J.; Masyrafah, H. "Post Tsunami Aid Effectiveness in Aceh: Proliferation and Coordination in Reconstruction". Working Paper; Wolfensohn Center for Development: Washington, DC, USA, 2008

[58] Fengler, W.; Ihsan, A.; and Kaiser, K. "Managing post disaster reconstruction finance: international experience in public financial management." World Bank Publications, 2008. https://doi.org/10.1596/1813-9450-4475

[59] Barenstein, J. D., and Pittet, D. "Post-Disaster Housing Reconstruction: Current Trends and Sustainable Alternatives for TsunamiAffected Communities in Coastal Tamil Nadu". Institute for Applied Sustainability to the Built Environment, University of Applied Sciences of Southern Switzerland, Canobbio, Switzerland, 2007. https://doi.org/10.1201/b13027-7

[60] Lester, R. "The World Bank perspective on national catastrophe risk management." Proceeding of the World Bank Conference, 2-3 June 2003, Washington, DC, 2003

[61] Fallahi, A. "Lessons learned from the housing reconstruction following the Bam earthquake in Iran," The Australian Journal of Emergency Management 22(1), 26-35, 2007.

[62] Flint, M., and Goyder, H. "Funding the Tsunami Response: A synthesis of initial findings". Tsunami Evaluation Coalition: London, UK, 2006.

[63] Aluko, 0. "Effects of Land Use Act on sustainable housing provision in Nigeria: the Lagos state experience". Journal of Sustainable Development, 5(1), 114-122, 2012. https://doi.org/10.5539/jsd.v5n1p114

[64] Rouhanizadeh B, Kermanshachi S, and Nipa T J. "Identification, Categorization, and Weighting of Barriers to Timely Post-Disaster Recovery Process". ASCE International Conference on Computing in Civil Engineering, 2019. https://doi.org/10.1061/9780784482445.006

[65] Steinberg, F. "Housing reconstruction and rehabilitation in Aceh and Nias, Indonesia-Rebuilding lives", Habitat International, 31, 150166, 2007. https://doi.org/10.1016/j.habitatint.2006.11.002

[66] Alexander, D. "Planning for post-disaster reconstruction". In I-Rec 2004 International Conference: Improving Post-Disaster Reconstruction in Developing Countries. Montreal, 2004

[67] Ozerdem A, Rufini G. "L’Aquila's reconstruction challenges have Italy learned from its previous earthquake disasters". Disasters 37(1):119-143, 2013. https://doi.org/10.1111/j.1467-7717.2012.01296.x

[68] Ranghieri, F., and Ishiwatari, M. "Learning from Mega-disasters: Lessons from the Great East Japan Earthquake." World Bank Publications: Washington, DC, USA, 2014. https://doi.org/10.1596/978-1-4648-0153-2_ov

[69] Gok, Y. "Geographic Comparison of Disaster Homes Built after Erzurum-Kars Earthquake (30 October 1983) and Aşkale Earthquakes (25-28 March 2004)," Eastern geographical review, 16(25), 67-88, 2011

[70] Gok, Y., Zaman, S., \& Altas, N. T. "The Socio-Economıc Analysis of Residences That Were Built After Askale Earthquake," Eastern Geographical Review, 12(8), 111-134, 2007.

[71] Safapour E, and Kermanshachi S." Identification and Categorization of Factors Affecting Duration of Post-Disaster Reconstruction of Interdependent Transportation Systems". ASCE Construction Research Congress (CRC), 2019

[72] Ibrahim, I., Muibi, K., Alaga, A., Babatimehin, O., Ige-Olumide, O., Mustapha, O., and Hafeez, S. "Suitability Analysis of Resettlement Sites for Flood Disaster Victims in Lokoja and Environs." World Environment 5, 101-111, 2015

[73] Grosskopf K. R. "Post-Disaster Recovery and Reconstruction Safety Training". International Journal of Disaster Resilience in the Built Environment 1(3), 322-333,2010. https://doi.org/10.1108/17595901011080904

[74] Maly, E., and Ishikawa, E. "Planning for relocation in recovery after the Great East Japan Earthquake: Considering residential relocation in contexts." International Journal of Disaster Resilience Built Environment 5, 243-259, 2014. https://doi.org/10.1108/ijdrbe01-2014-0014

[75] Robert B. Olshansky. "The challenges of planning for Post-Disaster Recovery". Building safer communities. Risk governance, Spatial planning, and Response to natural Hazards: Volume 58, 2010. http://doi.org/10.3233/978-1-60750-046-9-175

[76] Rouhanizadeh B, and Kermanshachi S. "Comparative Analysis of Public's and Decision-Maker's Perspectives on Socioeconomic Barriers Causing Delay in Post-disaster Recovery Processes". ASCE Construction Research Congress (CRC), 2019

[77] Rouhanizadeh B, and Kermanshachi S. "A Systematic Approach to Analysis and Prioritization of the Socioeconomic Policies and Legal barriers to Rapid Post Disaster Reconstruction". $7^{\text {th }}$ CSCE International Construction Specialty Conference (ICSC), 2019.

[78] Nipa T J., Kermanshachi S, and Ramaji I J. "Comparative Analysis of Strengths and Limitations of Infrastructure Resilience Measurement Methods". $7^{\text {th }}$ CSCE International Construction Specialty Conference (ICSC), 2019. 